\title{
Accumulation and removal of UVBR-induced DNA damage in marine tropical plankton subjected to mixed and simulated non-mixed conditions
}

\author{
Peter Boelen ${ }^{1,2, *}$, Marcel J. W. Veldhuis ${ }^{2}$, Anita G. J. Buma ${ }^{1}$ \\ ${ }^{1}$ Department of Marine Biology, University of Groningen, PO Box 14, 9750 AA Haren, The Netherlands \\ ${ }^{2}$ Department of Biological Oceanography, NIOZ, PO Box 59, 1790 AB Den Burg Texel, The Netherlands
}

\begin{abstract}
Accumulation and removal of UVBR (ultraviolet-B radiation: 280 to $315 \mathrm{~nm}$ )-induced DNA damage (cyclobutane pyrimidine dimers; CPDs) were studied in 2 size fractions $(0.2$ to 0.8 and 0.8 to $10 \mu \mathrm{m}$ ) of natural populations of tropical marine bacterio- and phytoplankton off Curaçao, Netherlands Antilles. Plankton was either directly sampled from the surface layer (mixed situation), or incubated in UVR-transparent bags at 2 water depths (simulated non-mixed situation). A DNA dosimeter was used to measure biologically effective UVBR doses as well as attenuation of biologically effective radiation in the surface layer. A significant difference in CPD level between the 2 plankton size fractions could not be measured. In the mixed as well as in the non-mixed situation, DNA damage was accumulated between 09:00 and 14:00 $\mathrm{h}$ irrespective of the variability in incident UVBR. Surface layer samplings on consecutive days showed a clear diel pattern of increase and decrease, indicating that, in the field, DNA damage is repaired or diluted during the afternoon or at night. No significant repair of DNA damage could be measured in samples that were incubated during the afternoon at 0.2 or $10 \mathrm{~m}$ depth. The UVBR sensitivity of surface-incubated plankton was expressed as the ratio between damage induced in the cells to damage induced in (unshielded and unrepaired) bare DNA. In both plankton size classes this ratio fluctuated around 0.32. In conclusion, the results show that plankton cells present in the clear waters off Curaçao undergo UVBR stress despite the fact that they are subjected to vertical mixing. No significant difference in CPD levels between 2 size fractions of plankton could be measured, suggesting that in this plankton population other aspects, e.g. repair capacities or cell morphology, were more important than cell size.
\end{abstract}

KEY WORDS: Cyclobutane pyrimidine dimers - DNA damage - DNA repair - Caribbean Sea · Marine bacteria $\cdot$ Mixing $\cdot$ Phytoplankton $\cdot$ Ultraviolet-B radiation, UVBR

\section{INTRODUCTION}

Tropical regions are characterized by high natural levels of ultraviolet-B radiation (UVBR, 280 to $315 \mathrm{~nm}$ ) (Madronich et al. 1995). Since marine tropical waters are typically oligotrophic, UVBR can penetrate deep into the water column (Smith \& Baker 1979). In a previous study we used a DNA dosimeter to measure the penetration of biologically effective (in this case DNA dam-

*E-mail: p.boelen@biol.rug.nl aging) UVBR in the central Atlantic Ocean and in several water types around Curaçao, Netherlands Antilles (Boelen et al. 1999). It was shown that biologically effective UVBR may penetrate deep into these waters giving $1 \%$ levels, compared to surface irradiance, down to $25 \mathrm{~m}$. Marine bacteria and small phototrophic plankton $(<1 \mu \mathrm{m})$ form the majority of the organisms in marine oligotrophic waters (Paul et al. 1985, Stockner 1988). Due to their small size this plankton is likely to be much more vulnerable to UVBR as compared to larger organisms. In several field studies (Jeffrey et al. 1996, Boelen et al. 2000, Buma et al. 2001) more UVBR- 
induced DNA damage was detected in small size classes of bacterio- and phytoplankton compared to bigger size fractions. Garcia-Pichel (1994) calculated that small plankton cells cannot efficiently use UVR-absorbing compounds as sunscreens. Taking all these aspects into consideration, it is reasonable to hypothesize that the high incident UVBR levels may have a strong impact on the biology of small plankton. Such stress can result in a decrease in primary (Behrenfeld et al. 1993) or bacterial production (Herndl et al. 1993, Aas et al. 1996, Visser et al. 1999) or damage to essential macromolecules, e.g. DNA (Jeffrey et al. 1996, Lyons et al. 1998, Weinbauer et al. 1999, Visser et al. 1999, Boelen et al. 2000). Alternatively, it may induce the synthesis of UV-absorbing compounds (Karentz et al. 1991b). Structural changes in DNA are considered to be one of the primary consequences of the deleterious effects of UVBR on the cellular level (Karentz et al. 1991a, Buma et al. 1995). Cyclobutane pyrimidine dimers (CPDs), especially thymine dimers (TT) are the predominant lesions induced by UVBR (Tyrrell 1986). These photoproducts block transcription and replication of the DNA, resulting in mutations or cell death (Setlow et al. 1963, Swenson \& Setlow 1966). Normally, cells are able to repair this type of DNA damage. There are 2 major mechanisms of DNA repair: excision (dark) repair and photodependent repair (Sancar \& Sancar 1988).

Theoretically the rate of DNA damage induction as well as that of photorepair in plankton is dependent on the prevailing light regime in the water column. CPD induction is mainly caused by UVBR, whereas photorepair of DNA damage depends on the intensity of ultraviolet-A radiation (UVAR, 315 to $400 \mathrm{~nm}$ ) and/or PAR (photosynthetically actve radiation) (Friedberg et al. 1995). Since the attenuation of UVBR in the water column is much higher than that of UVAR or PAR (Smith \& Baker 1979), the induction to repair ratio should be depth-related as well. Because plankton cells are transported in the upper water column as a result of vertical mixing, exposure of the cells to the different wavelength bands will strongly fluctuate. If a simple linear dose-response relationship for the induction as well as the repair of DNA damage were applicable, i.e. if the photochemical law of reciprocity would hold, the mean UVBR, UVAR and PAR doses in the wind mixed surface layer (WML) would be sufficient to predict effects on plankton organisms. However, there are indications that this is not always the case, especially for repair processes (Zagarese et al. 1998); not only the rate of photorepair, but also the induction of the repair system is light dependent (Mitani et al. 1996). This means that under fluctuating irradiance conditions, as experienced by plankton in the WML, repair rates may not always be optimal. Furthermore, the repair rate likely increases with increasing initial levels of CPDs (Fried- berg et al. 1995). Neale et al. (1998a,b) used non-linear dose-response relationships to model effects of ozone depletion on inhibition of photosynthesis in Antarctic phytoplankton. They showed that inhibition could be either decreased or enhanced by vertical mixing, depending on the depth of WML and the rate of mixing. Huot et al. (2000) developed a model of UV-induced DNA damage in oceanic bacterioplankton. Although the model could provide realistic estimates of DNA damage in small-sized plankton, they indicated that more information about CPD induction and repair rates in natural plankton communities is required.

To study the effects of the fluctuating light conditions in the WML on the induction and repair of DNA damage in natural marine tropical plankton populations, we compared field samples from the mixed surface layer with samples that were incubated in UVR-transparent bags to exclude vertical mixing. Accumulated DNA damage levels in 2 size fractions of plankton cells were normalized to the DNA effective doses the cells had received during incubation.

\section{MATERIALS AND METHODS}

Sampling site and incubation protocols. Ten identical experiments were carried out in April 1998 at Stn 'Buoy 1' near the island of Curaçao $\left(12^{\circ} \mathrm{N}, 69^{\circ} \mathrm{W}\right.$, Fig. 1), Netherlands Antilles. Stn Buoy 1 is located $100 \mathrm{~m}$ offshore, with a water depth of $15 \mathrm{~m}$. To study induction of DNA damage in non-mixed picoplankton assemblages, surface water was collected between 08.30 and 09:15 $\mathrm{h}$ and transferred into $20 \mathrm{l}$ polypropylene bags, which have a high transmission for UVR (Visser et al. 1999). These bags were incubated at $10 \mathrm{~m}$ depth or near the surface $(0.2 \mathrm{~m})$ until ca $14: 00 \mathrm{~h}(1.5 \mathrm{~h}$ after solar noon). To measure induction and repair of DNA damage in the afternoon, one bag that had been incubated near the surface during the morning was further incubated at $0.2 \mathrm{~m}$; another bag was transferred to $10 \mathrm{~m}$ depth. These bags were incubated until the end of the afternoon (17:00 to 18:00 h). Duplicate samples were taken from the bags before and at the end of the incubation period and filtered through 10 , 0.8 and $0.2 \mu \mathrm{m}$ pore-size polycarbonate filters (Poretics). The 0.8 and $0.2 \mu \mathrm{m}$ filters were frozen in liquid nitrogen and stored at $-80^{\circ} \mathrm{C}$ until DNA isolation. To determine the amount of DNA damage present in plankton circulating in the wind mixed layer before (around 09:00 h) and at the end of the morning incubation period (around 14:00 h) in situ samples were collected at the surface and at $10 \mathrm{~m}$ depth. The irradiance conditions in the surface layer were determined using a DNA dosimeter and a PUV 500 profiling radiometer (see below). The PUV radiometer was equipped with a 


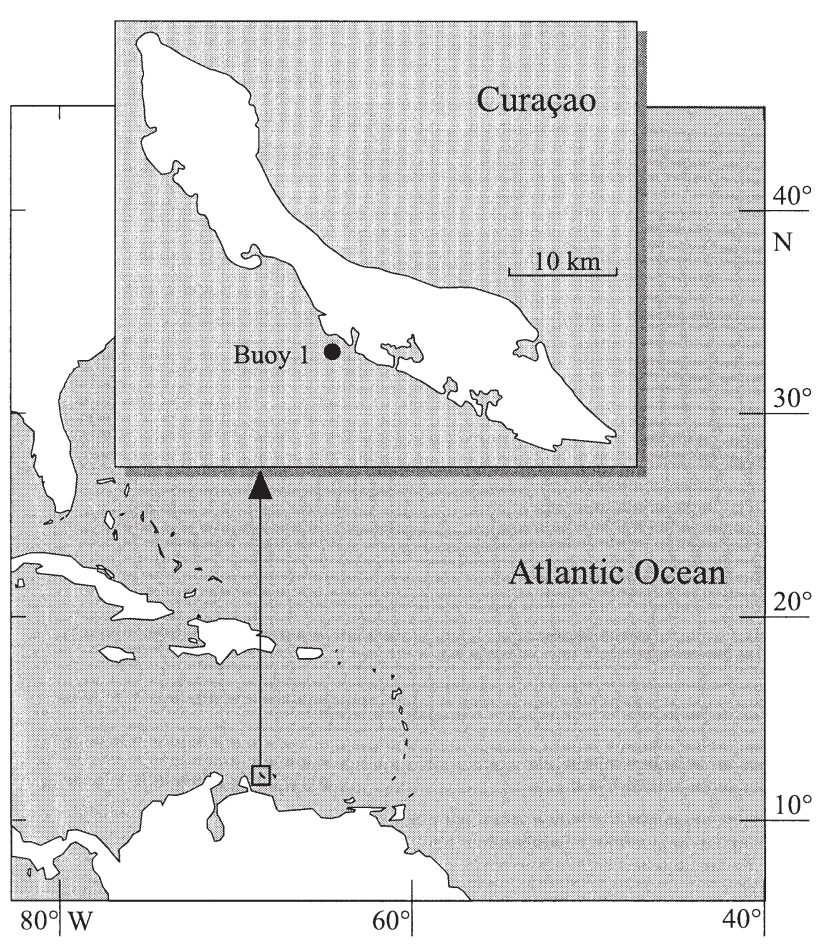

Fig. 1. Sample location off Curaçao $\left(12^{\circ} \mathrm{N}, 69^{\circ} \mathrm{W}\right)$, Netherlands Antilles

temperature profiler. The temperature profiles demonstrated that the water column was completely mixed. The temperature of the water column during the experimental period was $27.3 \pm 0.2^{\circ} \mathrm{C}$.

Irradiance conditions in the surface layer. Biologically effective (in this case DNA-damaging) doses (BEDs) and attenuation of biologically effective radiation in the water column were measured using a DNA dosimeter as described before (Boelen et al. 1999). In short, small acid-cleaned quartz tubes were filled with a solution of $10 \mu \mathrm{g} \mathrm{ml}^{-1}$ calf thymus DNA (Sigma) in TEbuffer (10 mM Tris- $\mathrm{HCl} \mathrm{pH}=8.0,1 \mathrm{mM}$ EDTA). The tubes were sealed with parafilm after which duplicate tubes were incubated at several water depths for the duration of the experiment. After incubation the tubes were kept in the dark at $4^{\circ} \mathrm{C}$ during transportation before the DNA solution was stored at $-20^{\circ} \mathrm{C}$ until CPD analyses. BEDs were expressed as number of induced CPDs per million nucleotides (CPD $\mathrm{Mnucl}^{-1}$ ). The average vertical attenuation coefficient for the induction of DNA damage $\left(K_{\mathrm{bd}}\right)$ was determined from 6 linear regressions of natural logarithmic BEDs against depth. BEDs at other (incubation) depths were calculated using dosimeter data together with the average attenuation coefficient, assuming constant $K$ values over depth. Around solar noon attenuation coefficients of 305, 320, 340, $380 \mathrm{~nm}$ and PAR were measured using a Biospherical Instruments Model PUV 500 profiling radiometer.
DNA isolation and quantification. DNA was extracted from the filters as described before (Boelen et al. 2000). In brief, the filters were incubated at $60^{\circ} \mathrm{C}$ for 30 min with CTAB isolation buffer $(2 \%$ [w/v] CTAB [Sigma], 1.4 M NaCl, 0.2\% [v/v] 2-mercaptoethanol, $20 \mathrm{mM}$ EDTA, $100 \mathrm{mM}$ Tris- $\mathrm{HCl} \mathrm{pH}=8.0$ ). After chloroform/isoamylalcohol purification the DNA was precipitated with isopropanol and subsequently washed with $80 \%$ ice-cold ethanol. The DNA was dried under vacuum and resuspended in TE buffer $(10 \mathrm{mM}$ Tris$\mathrm{HCl} \mathrm{pH}=8.0,1 \mathrm{mM}$ EDTA). To remove RNA the extracts were incubated for $1 \mathrm{~h}$ with $75 \mu \mathrm{g} \mathrm{ml}^{-1}$ RNase (Boehringer Mannheim) at room temperature. The amount of DNA was determined fluorometrically using Picogreen dsDNA quantitation reagent (dilution 1:400, Molecular Probes) on a 1420 Victor multilabel counter (EG\&G Wallac, excitation 485 nm, emission $535 \mathrm{~nm}$ ).

Quantification of cyclobutane pyrimidine dimers. The amount of CPDs in DNA was determined using the H3 antibody (Roza et al. 1988) together with a slightly modified immunodotblot procedure (Vink et al. 1994, Boelen et al. 1999). The H3 antibody is raised against cyclobutane thymine dimers (TT) but has also a high affinity for 5'TC dimers (Fekete et al. 1998). For clarity, and since TT and 5'TC form the majority of the CPDs induced under natural conditions (Friedberg et al. 1995), we chose to use the term CPD in the following sections. Heat-denaturated DNA samples (dosimeter DNA: 20 ng, other samples: $100 \mathrm{ng}$ ) were dotblotted (Minifold I SRC96D dotblot apparatus; Schleicher \& Schuell) onto nitrocellulose filters (Protran BA79, pore size $0.1 \mu \mathrm{m}$, Schleicher \& Schuell). To immobilize the DNA, the filters were baked at $80^{\circ} \mathrm{C}$ for $1 \mathrm{~h}$, after which they were incubated in $5 \%(\mathrm{w} / \mathrm{v})$ skimmed-milk powder in PBS-T (PBS + 0.1\% [v/v] Tween 20 [Sigma]) for $30 \mathrm{~min}$ at room temperature. Filters were incubated overnight at $4^{\circ} \mathrm{C}$ with the $\mathrm{H} 3$ antibody $\left(2.1 \mu \mathrm{g} \mathrm{ml}^{-1}\right.$ in $0.5 \%$ milk powder-PBS-T), after which they were incubated with rabbit-anti-mouse-peroxidase antibody (Dako) (diluted 1:2000 in 0.5\% milk powder-PBS-T) for $2 \mathrm{~h}$ at room temperature. Finally the filters were transferred to $15 \mathrm{ml}$ ECL detection reagent (Amersham) for $1 \mathrm{~min}$ and sealed in Photogene development folders (GibcoBRL). In between all steps the filters were washed 3 times in PBS-T (10 min). Photographic films (Amersham Hyperfilm ECL) were exposed to the filters for 1 to $30 \mathrm{~min}$. The films were developed, scanned and analyzed as described before (Boelen et al. 1999). To allow quantification of the amount of damage in the sample DNA, the samples were compared with a dilution series of standard DNA. The amount of CPDs in the standard DNA was determined before by calibrating it against DNA isolated from irradiated Hela cells. The amount of CPDs in this DNA was determined by Roza et al. (1988) by means of HPLC. The immuno- 
assay is a highly sensitive assay and it is possible to detect less than 1 CPD Mnucl ${ }^{-1}$ (Boelen et al. 2000). The actual detection limit depends on the amount of DNA that is used for the assay and on the exposure time of the films. In this study the detection limit was $<20$ CPD Mnucl ${ }^{-1}$.

Flow cytometry. Occasionally, plankton composition and relative DNA content per plankton cluster were determined using flow cytometry (Coulter Epics-EliteESP) in combination with the nucleic acid stain Picogreen as described by Veldhuis et al. (1997). This gives an indication of which plankton groups contributed most to the total amount of DNA damage. The exact contribution is difficult to predict since there may be differences in sensitivity to DNA damage and yield of DNA isolation between the various groups. Four clusters were identified: non-phototrophic bacteria, Prochlorococcus spp., Synechococcus spp., and small eukaryotic algae.

Pigment composition. Phytoplankton class abundance was further investigated with HPLC pigment analyses. Samples (10 1) of surface water were taken in the morning (16, 17, 20, 21, 22, 23 and 28 April 1998) and filtered over a Whatman GF/F glass-fiber filter. The filters were frozen immediately in liquid nitrogen and stored at $-80^{\circ} \mathrm{C}$ until further analyses. Pigments were determined by HPLC as described by Kraay et al. (1992). Divinyl-chlorophyll a concentrations were determined as described by Veldhuis \& Kraay (1990). Phytoplankton class abundances were calculated from the pigment data using the Chemtax program as introduced by Mackey et al. (1996).

\section{RESULTS}

\section{Irradiance conditions and plankton composition in the surface layer}

Daily BEDs as measured at $0.5 \mathrm{~m}$ depth varied during the experimental period (Fig. 2). The lowest dose (525 $\mathrm{CPD} \mathrm{Mnucl}^{-1}$ ) was measured on 20 April on a rainy day. The highest dose was measured $2 \mathrm{~d}$ later (946 CPD Mnucl-1). The attenuation of UVR and PAR was calculated from dosimeter and radiometer data (one example shown in Fig. 3). Variation in attenuation during the experimental period was small (Table 1). The average attenuation of biologically effective UVR as measured using the DNA dosimeter was higher $\left(0.28 \mathrm{~m}^{-1}\right)$ than radiometer results $\left(\max . K_{\mathrm{d}}: 0.21 \mathrm{~m}^{-1}\right.$ at $305 \mathrm{~nm}$ ). UVR penetration was wavelength dependent: longer UVR wavelengths were less attenuated than shorter wavelengths (Table 1). The BEDs the plankton community received during incubation were calculated from the average attenuation coefficient for biologically effective UVR and the BEDs as measured with dosimeter tubes that were incubated at a fixed depth during the day. When averaged over all 10 sampling dates, calculated BEDs ranged between 14 CPD $\mathrm{Mnucl}^{-1}$ (afternoon incubation at $10 \mathrm{~m}$ ) and $847 \mathrm{CPD}$ $\mathrm{Mnucl}^{-1}$ (whole day incubation at $0.2 \mathrm{~m}$ ) (Table 2).

Flow cytometric DNA labeling of the plankton community indicated that generally more than $70 \%$ of the DNA originated from non-phototrophic bacteria. The remaining $30 \%$ of the DNA was equally distributed between Prochlorococcus spp., Synechococcus spp. and small eukaryotic algae. Samples that were taken during size fractionation (between the 0.2 and the $0.8 \mu \mathrm{m}$ filter) showed that, besides small bacteria and Prochlorococcus spp., part of the Synechococcus spp. population also passed the $0.8 \mu \mathrm{m}$ filter. This means that the $0.8 \mu \mathrm{m}$ fraction contained all eukaryotic cells as well as a significant portion of the Synechococcus spp. (30 to $70 \%$ ), whereas the $0.2 \mu \mathrm{m}$ fraction included phototrophic prokaryotes, but mainly non-phototrophic bacteria. Significant differences in plankton composition between field samples and incubated samples were not found. Generally the pigment concentration and composition did not change much during the experimental period. (Divinyl-)chlorophyll a concentrations varied between 171 and $363 \mathrm{ng} \mathrm{l}^{-1}$. Prochlorophytes and cyanobacteria comprised the largest fraction of the phytoplankton. The estimated contribution of prochlorophytes to the total amount of (divinyl-)chlorophyll a varied between 23 and $53 \%$ (on

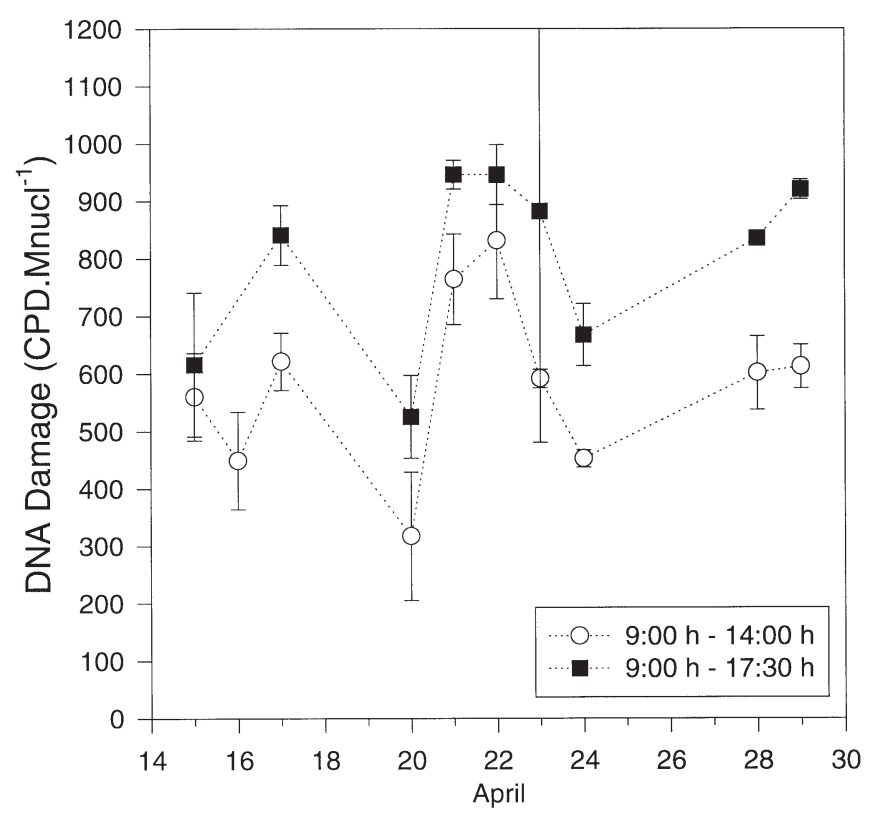

Fig. 2. Induced DNA damage in DNA dosimeters during 10 days between 15 and 29 April 1998. Dosimeters were incubated at $0.5 \mathrm{~m}$ depth from 09:00 $\mathrm{h}$ until ca 14:00 $\mathrm{h}$ and from 09:00 $\mathrm{h}$ until the end of the afternoon (17:00 to $18: 00 \mathrm{~h})$ 


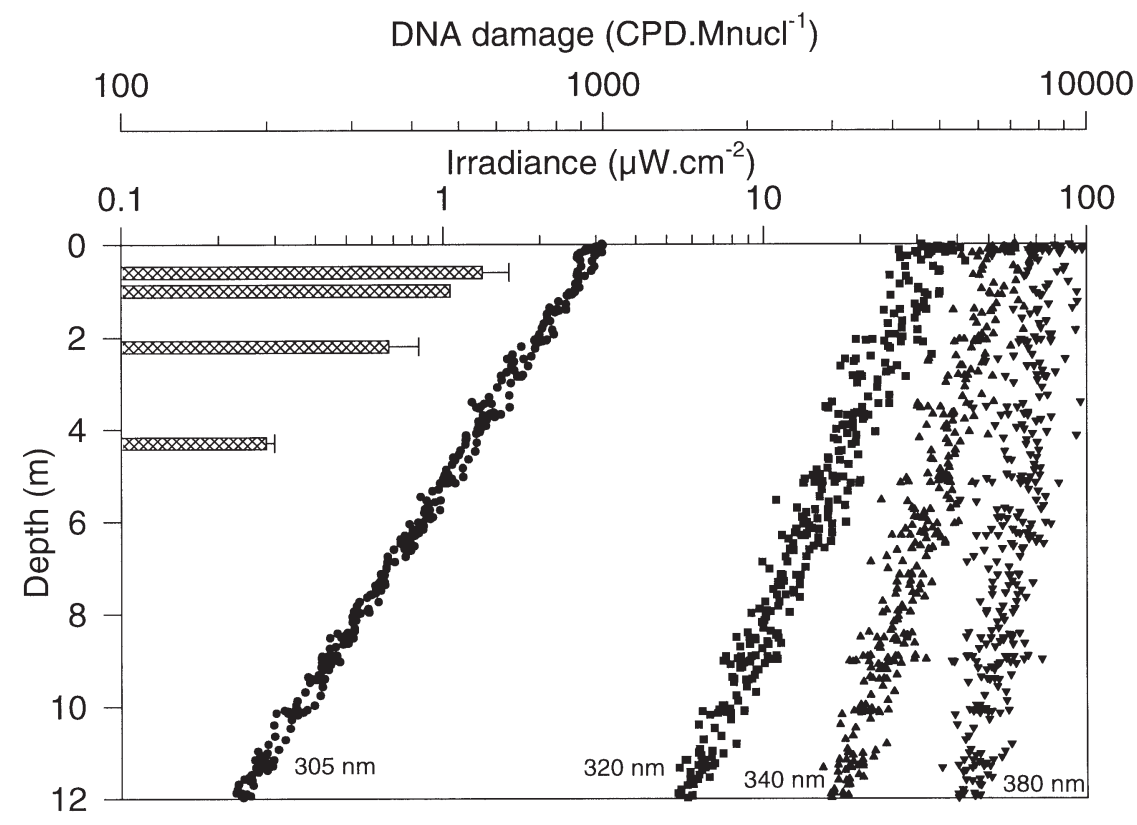

Fig. 3. Attenuation of 4 wavelengths of UVR (symbols) and biologically effective (DNA damaging) UVR (bars) at the sample location on 15 April 1998. To measure biologically effective UVR a DNA based dosimeter was used which was incubated at several depths from 09:30 to 13:30 h average $39 \%$ ). Cyanobacteria contributed on average $29 \%$ to the total amount of (divinyl-)chlorophyll a. The rest (eukaryotic part) of the phototrophic community consisted mainly of prymnesiophytes (17\% of total [divinyl-]chlorophyll a).

\section{DNA damage in the surface layer}

Surface samples collected in the WML on 10 days in April 1998 showed a clear daily variation in DNA damage (Fig. 4). In samples collected in the early morning significantly less (paired $t$-test, $\mathrm{p}<1 \%$ ) DNA damage was detected than in samples that were collected around 14:00 h. Also, in most cases, morning levels were lower than 14:00 $\mathrm{h}$ levels from the previous day. On some days no DNA damage could be detected in the morning samples. The highest amount of DNA damage was measured in the 0.8 to $10 \mu \mathrm{m}$ fraction on 21 April (190 CPD Mnucl ${ }^{-1}$ ). Generally we could not measure a significant difference between the 2 size fractions. Compared to the 14:00 $\mathrm{h}$ surface samples, slightly less (significant for the 0.2 to $0.8 \mu \mathrm{m}$ size fraction, paired $t$-test, $\mathrm{p}<1 \%$ ) DNA damage was measured at $10 \mathrm{~m}$ in the WML (one example shown in Fig. 5).

\section{DNA damage in the incubated samples}

The amount of DNA damage as measured in plankton samples that were incubated near the surface was substantially higher compared to samples collected in the WML (one example shown in Fig. 5). The highest

Table 2. Average CPD accumulation (total and per hour, $\pm \mathrm{SD}, \mathrm{n}=10$ ) measured in 2 size fractions of picoplankton incubated in UV-transparent bags compared to the calculated biologically effective dose (BED) the plankton had received during the incubations. Initial damage values (09:00 or 14:00 h) were subtracted from noon or afternoon values. The mean damage ratio (MDR) is the mean of the ratios of CPD abundance in the plankton cells to the damage induced in bare DNA (DNA dosimeter). Repair of DNA damage was studied by incubating bags at the surface until ca 14:00 h, after which bags were transferred to $10 \mathrm{~m}$ depth and incubated further during the rest of the afternoon ('repair' afternoon). Since during this period at this depth UVBR levels were very low and in some cases repair rates exceeded DNA damage induction rates, the MDR was not calculated here. CPD $\mathrm{Mn}^{-1}$ : CPD per million nucleotides

\begin{tabular}{|c|c|c|c|c|c|c|c|c|}
\hline \multirow[t]{2}{*}{ Bag } & \multicolumn{2}{|c|}{ BED } & \multicolumn{3}{|c|}{0.2 to $0.8 \mu \mathrm{m}$ fraction } & \multicolumn{3}{|c|}{0.8 to $10 \mu \mathrm{m}$ fraction } \\
\hline & $\begin{array}{l}\text { DNA damage } \\
\left(\mathrm{CPD} \mathrm{Mn}^{-1}\right)\end{array}$ & $\begin{array}{c}\text { Rate } \\
\left(\mathrm{CPD} \mathrm{Mn}^{-1} \mathrm{~h}^{-1}\right)\end{array}$ & $\begin{array}{l}\text { DNA damage } \\
\left(\mathrm{CPD} \mathrm{Mn}^{-1}\right)\end{array}$ & MDR & $\begin{array}{c}\text { Rate } \\
\left(\mathrm{CPD} \mathrm{Mn}^{-1} \mathrm{~h}^{-1}\right)\end{array}$ & $\begin{array}{l}\text { DNA damage } \\
\left(\mathrm{CPD} \mathrm{Mn}^{-1}\right)\end{array}$ & MDR & $\begin{array}{c}\text { Rate } \\
\left(\mathrm{CPD} \mathrm{Mn}^{-1} \mathrm{~h}^{-1}\right)\end{array}$ \\
\hline $0.2 \mathrm{~m}(09: 00-14: 00 \mathrm{~h})$ & $647 \pm 168$ & $132 \pm 32$ & $211 \pm 78$ & $0.32 \pm 0.10$ & $42 \pm 15$ & $192 \pm 88$ & $0.30 \pm 0.13$ & $38 \pm 15$ \\
\hline $10 \mathrm{~m}(09: 00-14: 00 \mathrm{~h})$ & $51 \pm 13$ & $10 \pm 3$ & $27 \pm 22$ & $0.51 \pm 0.44$ & $6 \pm 5$ & $22 \pm 15$ & $0.45 \pm 0.29$ & $4 \pm 3$ \\
\hline $0.2 \mathrm{~m}(90: 00-17.30 \mathrm{~h})$ & $847 \pm 166$ & $103 \pm 19$ & $258 \pm 65$ & $0.32 \pm 0.07$ & $31 \pm 8$ & $274 \pm 68$ & $0.33 \pm 0.06$ & $33 \pm 8$ \\
\hline 10 m ('repair' afternoon) & $14 \pm 7$ & $5 \pm 3$ & $-22 \pm 60$ & - & $-6 \pm 18$ & $28 \pm 49$ & - & $7 \pm 13$ \\
\hline
\end{tabular}


DNA damage level was found on 23 April in the 0.8 to $10 \mu \mathrm{m}$ fraction (403 CPD Mnucl ${ }^{-1}$ ). Again, no significant differences between the 2 size fractions were found. Accumulation of DNA damage measured in plankton samples that were incubated at $10 \mathrm{~m}$ during the morning period was far less than those incubated close to the surface (Fig. 6A,C). Further afternoon CPD accumulation was generally found at $0.2 \mathrm{~m}$. On the other hand, no significant changes in DNA damage were found in the samples that were transferred to $10 \mathrm{~m}$ (Fig. 6B,D).

Highest CPD accumulation rates were found during the morning hours on 28 April (62 CPD Mnucl ${ }^{-1} \mathrm{~h}^{-1}$ ). Mean daily accumulation rates at the surface were $31 \mathrm{CPD} \mathrm{Mnucl}^{-1} \mathrm{~h}^{-1}$ for the 0.2 to $0.8 \mu \mathrm{m}$ size fraction and $33 \mathrm{CPD} \mathrm{Mnucl}{ }^{-1} \mathrm{~h}^{-1}$ for the 0.8 to $10 \mu \mathrm{m}$ fraction (Table 2). Slightly, but not significant, higher CPD accumulation rates (42 and $38 \mathrm{CPD} \mathrm{Mnucl}{ }^{-1} \mathrm{~h}^{-1}$ ) were found in bags that were incubated from 09:00 until 14:00 h. To get insight into the sensitivity of the 2 plankton size fractions mean damage ratios (MDRs) were calculated. This is the DNA damage accumulated in the plankton divided by the amount of biologically effective irradiation, expressed as CPD accumulation in bare DNA, that the organisms had actually received. MDRs varied between 0.30 as measured in bags that were incubated near the surface and 0.51 in bags that were incubated at $10 \mathrm{~m}$ (Table 2). Due to the high variation between
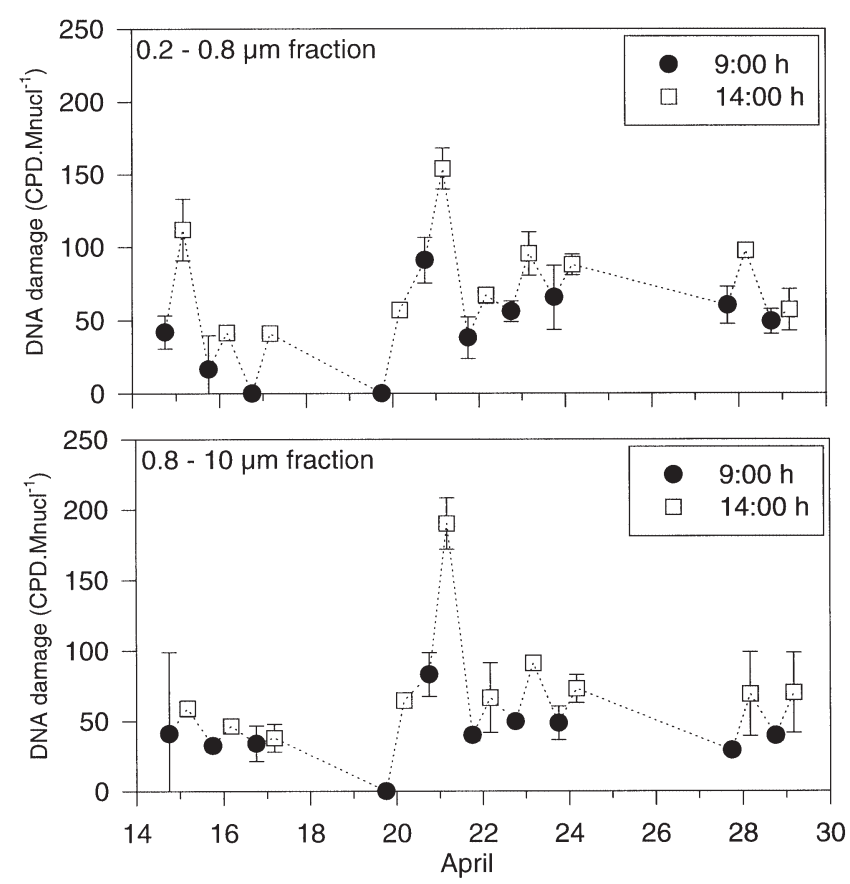

Fig. 4. Diurnal changes in DNA damage measured in 2 size fractions of surface field samples collected on 10 different days near Curaçao samples, no significant differences between the 2 incubation depths could be demonstrated.

\section{DISCUSSION}

Our results clearly show that DNA damage accumulates in bacterio- and phytoplankton in the WML throughout the day (Fig. 4). This implies that these organisms undergo UVBR stress under natural solar conditions despite the fact that they are subjected to vertical mixing. This form of UV stress may reduce growth, as a result of CPD-mediated cell cycle arrest, although we do not have data available to support this.

During the research period, the water column at Stn Buoy 1 was well mixed. The water column was furthermore homogeneous with respect to phytoplankton concentration and composition. In addition, light attenuation in the water column did not vary much during the experimental period (Table 1). In samples that were collected in the morning, lower, sometimes undetectable CPD levels were measured compared to midday values of the previous day. This suggests that DNA damage is repaired during the afternoon or night. It is also possible that a decrease in CPD level could be due to the transport of less-damaged cells from deeper waters through mixing combined with a reduced rate of CPD production during afternoon and night (Huot et al. 2000). Another possibility is that damage is 'diluted' by growth or has disappeared by lysis of damaged cells. Repair during the afternoon could be mediated by photoreactivation or by excision repair (dark repair), or both. During the night DNA can only be repaired by excision repair. In summary, it is difficult to quantify the individual contribution of all these processes separately from the observed decrease in DNA damage. Jeffrey et al. (1996) demonstrated accumulation of DNA damage during the day in plankton assemblages in the Gulf of Mexico. They showed that CPD levels decreased immediately after sunset. During this period synthesis of new DNA (measured as thymidine incorporation) was not high enough to explain the decrease in CPDs, suggesting that removal of CPDs was mainly caused by excision (dark) repair and that DNA damage was not 'diluted' by growth (Jeffrey et al. 1996). This is confirmed by our incubation experiments where we incubated CPD containing plankton samples at $10 \mathrm{~m}$ depth (Fig. 6B,D). Here, biologically effective UVBR levels were only $6 \%$ of surface levels, but UVAR and PAR, involved in photorepair, were still high, as judged from $K_{\mathrm{d}}$ values (Table 1). Nevertheless, we could not detect a significant decrease in CPD levels, suggesting that photorepair is not the prevailing pathway for CPD removal in these organisms, although we cannot completely rule 

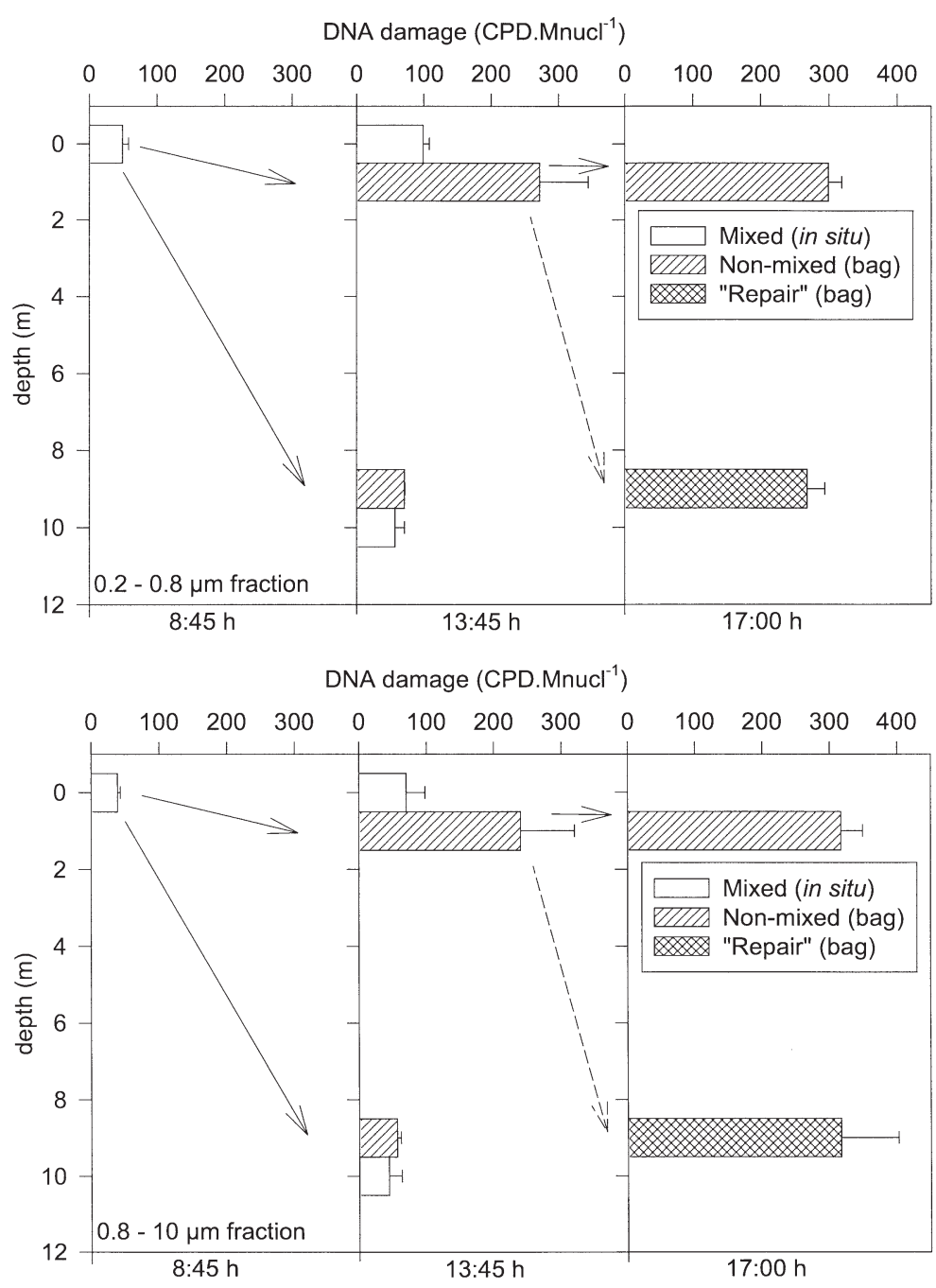

Fig. 5. DNA damage during the day (29 April 1998) measured in 2 size fractions of picoplankton subjected to mixed (in situ samples) or nonmixed (incubations in UV-transparent bags) situations. A number of bags which were incubated near the surface until ca 14:00 h were transferred to $10 \mathrm{~m}$ depth (stippled arrow, biologically effective UVBR level ca $6 \%$ of surface level) to study repair of DNA damage

out the possibility that UVAR and PAR levels at $10 \mathrm{~m}$ depth were not sufficient to support photorepair. In contrast, in the model of Huot et al. (2000) photorepair appears to be important: the calculated values of DNA damage matched the measured values the best when photorepair was taken into account. Kaiser \& Herndl (1997) reported recovery of protein synthesis in marine bacterioplankton under exposure to UVAR and PAR. In marine viruses host-mediated photorepair is potentially essential for the maintenance of high concentrations of viruses in surface waters (Weinbauer et al. 1997, Wilhelm et al. 1998).

It is unclear whether DNA damage is uniformly distributed over all cells or whether most of the damage is accumulated in a few heavily damaged cells, as suggested by Buma et al. (1995). Although DNA replication, and thereby cell division, cannot be completed until most of the DNA damage is repaired, it is a possibility that, due to an unequal distribution of DNA damage, part of the population replicates in a normal way, whilst damaged cells eventually die and disappear by lysis. Within this context, it would be interesting to consider potential interactions between nutrient/substrate limitation and UVBR stress. As has been demonstrated by others (Choi et al. 1999 and references therein), a large fraction of the bacterioplankton in marine waters is metabolically inactive as a result of substrate limitation. Suboptimal metabolic activity in these cells would hamper repair of DNA damage, and thereby contribute to further accumulation of DNA damage in these cells. In return, damage accumulation would then decrease viability in this fraction of the bacterioplankton community. The low repair rates and residual DNA damage levels (morning samples) reported in this study seem to support this hypothesis. In future experiments it would be useful to measure viability and DNA damage in individual cells by combining flow cytometry and specific fluorescent stains.

In contrast to earlier experiments by us and others (Jeffrey et al. 1996, Lyons et al. 1998, Boelen et al. 2000), where more DNA damage was detected in the small size fraction compared to the bigger size fraction, we could not find a significant difference in CPD levels between the 2 size fractions. Our sampling site was located in a coral reef area. Although Lyons et al. (1998) generally detected less DNA damage in the $>0.8 \mu \mathrm{m}$ size fraction compared to the small size fraction, they reported on occasions higher DNA damage levels in the $>0.8 \mu \mathrm{m}$ size fraction collected in the water column from a reef area. Jeffrey et al. (1996) measured more damage in the $>0.8 \mu \mathrm{m}$ fraction compared to the smaller fraction during the night, probably caused by differences in repair rate. Laurion \& Vincent (1998) demonstrated in subarctic lakes that cyanobacteria-dominated picophytoplankton were more resistant to UVBR than could be expected from relationships based only on cell size. The results show that in the plankton population that was present at our sample location other aspects, e.g. repair capacities or cell morphology, were more important than cell size. 

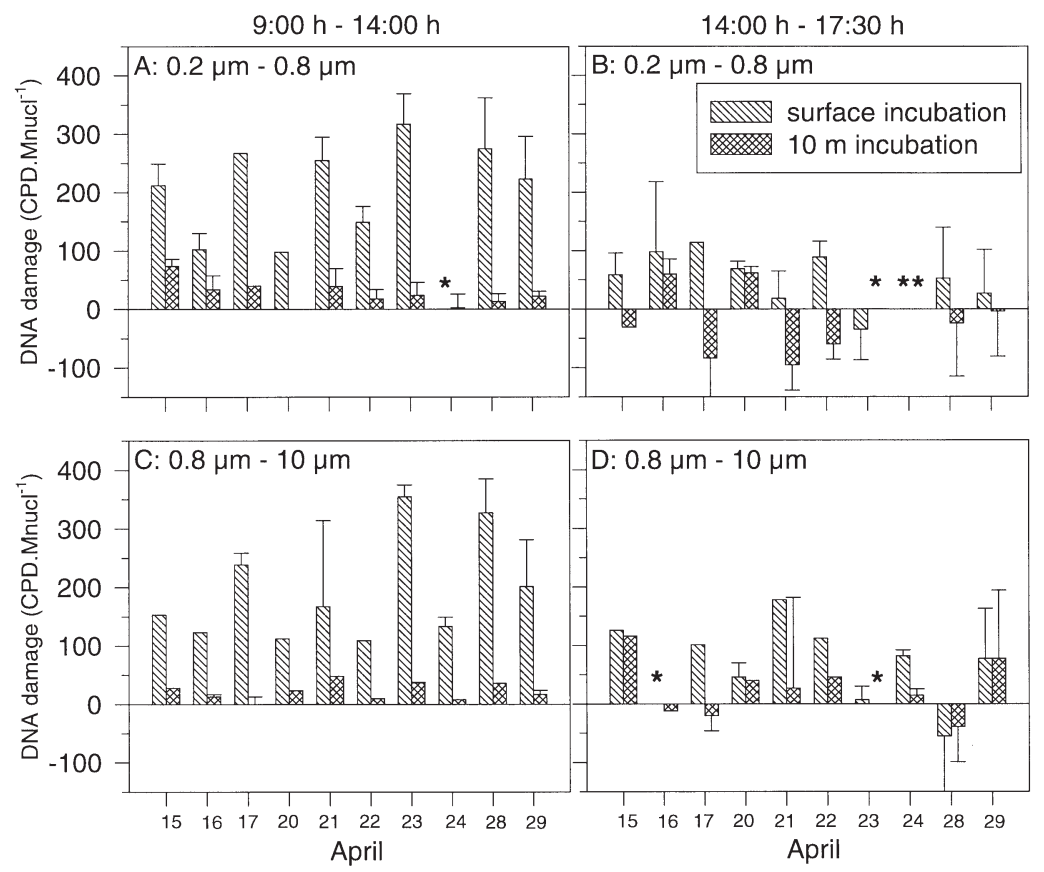

Fig. 6. Accumulation and repair of DNA damage measured in 2 size fractions of picoplankton incubated in UV-transparent bags at 2 depths. The experiments were carried out between 15 and 29 April 1998. To measure induction or repair of DNA damage in the afternoon, some bags that had been incubated near the surface from 09:00 until ca 14:00 h were further incubated at $0.2 \mathrm{~m}$; other bags were transferred to $10 \mathrm{~m}$ depth (biologically effective UVBR level ca $6 \%$ of surface level). Samples were taken from these bags at the end of the afternoon $(17: 30 \mathrm{~h})$. Initial damage values $(09: 00$ or 14:00 h) were subtracted from noon or afternoon values. (A) 0.2 to $0.8 \mu \mathrm{m}$ size fraction, incubated from 09:00 until 14:00 h. (B) 0.2 to $0.8 \mu \mathrm{m}$ size fraction, incubated from 14:00 until 17:30 h. (C) 0.8 to $10 \mu \mathrm{m}$ size fraction, incubated from 09:00 until 14:00 h. (D) 0.8 to $10 \mu \mathrm{m}$ size fraction, incubated from 14:00 until $17: 30$ h. ${ }^{*}$ Not determined

In the WML (mixed situation) DNA damage was accumulated during morning hours. We assumed that the water column at our sampling location was totally mixed since water depth was only $15 \mathrm{~m}$ and the mean wind speed at the sampling location was high enough to homogenize the water column. High resolution temperature profiles that were collected every day around noon confirmed this assumption of total mixing (results not shown). Strikingly, there was a small but significant difference between surface and $10 \mathrm{~m}$ samples for the 0.2 to $0.8 \mu \mathrm{m}$ size fraction. Obviously, mixing rate was low enough to allow for variability in UVBR levels received by the plankton within the WML. For instance, a portion of the plankton assemblage may have resided for a prolonged period at greater depth during UVBR peak hours. This stresses the importance of including mixing rate, apart from mixing depth, in UVBR effect studies.

As expected, the amount of accumulated DNA damage in the incubated samples depended on the amount of biologically effective UVBR the cells had received during incubation (Table 2). Highest MDR values $(0.45$ to 0.51$)$ were determined for plankton in bags that were incubated at $10 \mathrm{~m}$ depth. Due to the low UVBR levels at this depth, variation in MDR values were high. Furthermore, at this depth a relatively small error in the calculated $K_{\mathrm{bd}}$ value strongly influenced the calculated UVBR level. For the surface incubations lower MDR values (0.30 to 0.33 ) were calculated. Due to the high variation in MDRs between the samples, significant differences between the several groups (i.e. deep, surface) could not be demonstrated. The mean of all 'surface' MDRs was 0.32 for the 0.2 to $0.8 \mu \mathrm{m}$ size fraction as well as for the 0.8 to $10 \mu \mathrm{m}$ size fraction. This implies that in this case $32 \%$ of the DNA is damaged when compared to bare DNA as present in the DNA dosimeter. This difference in CPD level must be the result of repair, intracellular shielding (including packaging of DNA) or differences in DNA sensitivity (e.g. AT-composition).

To investigate the effects of vertical mixing on the induction of DNA damage in picoplankton we estimated the MDR values for the samples that were collected in the WML at 14:00 h. Therefore we first assessed the mean BED the plankton had received during the morning while circulating through the water column. To this end we used the calculated $K_{\text {bd }}$ values and surface BEDs together with the depth of the WML $(15 \mathrm{~m})$ as described before (Boelen et al. 2000). Thereby we neglected the effect of mixing rate, horizontal advection and possible changes in plankton composition during the day. However, small differences in accumulation of DNA damage between the in situ surface and $10 \mathrm{~m}$ samples (Fig. 5) showed that probably these factors cannot be completely neglected at our study site. Nevertheless, for reasons of simplicity and because differences in CPD accumulation between the 2 depths were small, we decided to use mean WML BEDs for our MDR calculations. Calculated MDR values were 0.23 for the 0.2 to $0.8 \mu \mathrm{m}$ size fraction as well as for the 0.8 to $10 \mu \mathrm{m}$ size fraction. This might imply that plankton cells in the WML are less vulnerable to UVBR compared to non-mixed conditions (i.e. incubation experiments), but due to the fact that the variation between the samples was high, significant differences between the 2 groups (mixed, nonmixed) could not be demonstrated.

In conclusion, in this study we showed that, at our sampling location, there was a net accumulation of DNA 
damage in plankton during the day, implying that these organisms undergo UVBR stress. Incubation experiments indicated that during the day repair rates are low when compared to DNA damage accumulation rates, suggesting that an essential part of the DNA damage is repaired after sunset by excision (dark) repair. In future experiments we want to follow DNA accumulation during several daily cycles, to gain more insight into daily patterns of damage induction and repair.

Acknowledgements. The authors wish to thank G. W. Kraay, P. M. Visser, J. J. Poos and the Ecological Institute CARMABI at Curaçao for technical assistance, A. A. Vink for the H3 antibody, L. Roza for providing the Hela reference DNA, G. J. Herndl for providing the PUV 500 radiometer and W. W. C. Gieskes for critically reading the manuscript. Further, we wish to thank P. J. Neale and 2 anonymous reviewers for constructive suggestions on an earlier version of the manuscript. The field research was partly sponsored by the Netherlands Organization for the Advancement of Research (NWO).

\section{LITERATURE CITED}

Aas P, Lyons MM, Pledger R, Mitchell DL, Jeffrey WH (1996) Inhibition of bacterial activities by solar radiation in nearshore waters and the Gulf of Mexico. Aquat Microb Ecol 11:229-238

Behrenfeld M, Hardy J, Gucinski H, Hanneman A, Lee HI, Wones A (1993) Effects of ultraviolet-B radiation on primary production along latitudinal transects in the South Pacific Ocean Mar Environ Res 35:349-363

Boelen P, Obernosterer I, Vink AA, Buma AGJ (1999) Attenuation of biologically effective UV radiation in tropical Atlantic waters, as measured with a biochemical DNA dosimeter. Photochem Photobiol 69:34-40

Boelen P, de Boer MK, Kraay GW, Veldhuis MJW, Buma AGJ (2000) UVBR induced DNA damage in natural marine picoplankton assemblages in the tropical Atlantic Ocean. Mar Ecol Prog Ser 193:1-9

Buma, AGJ, van Hannen EJ, Roza L, Veldhuis MJW, Gieskes WWC (1995) Monitoring ultraviolet-B-induced DNA damage in individual diatom cells by immunofluorescent thymine dimer detection. J Phycol 31:314-321

Buma AGJ, de Boer MK, Boelen P (2001) Depth distributions of DNA damage in Antarctic marine phyto- and bacterioplankton exposed to summertime ultraviolet radiation. J Phycol 37:200-208

Choi JW, Sherr BF, Sherr EB (1999) Dead or alive? A large fraction of ETS-inactive marine bacterioplankton cells, as assessed by reduction of CTC, can become ETS-active with incubation and substrate addition. Aquat Microb Ecol 18:105-115

Fekete A, Vink AA, Gaspar S, Berces A, Modos K, Ronto G, Roza L (1998) Assessment of the effects of various UV sources on inactivation and photoproduct induction in phage T7 dosimeter. Photochem Photobiol 68:527-531

Friedberg EC, Walker GC, Siede W (1995) DNA repair and mutagenesis. ASM Press, Washington, DC

Garcia-Pichel F (1994) A model for internal self-shading in planktonic organisms and its implications for the usefulness of ultraviolet sunscreens. Limnol Oceanogr 39:1704-1717
Herndl GJ, Müller-Niklas G, Frick J (1993) Major role of ultraviolet-B in controlling bacterioplankton growth in the surface layers of the ocean. Nature 361:717-719

Huot Y, Jeffrey WH, Davis RF, Cullen JJ (2000) Damage to DNA in bacterioplankton: a model of damage by ultraviolet radiation and its repair as influenced by vertical mixing. Photochem Photobiol 72:62-74

Jeffrey WH, Pledger RJ, Aas P, Hager S, Coffin RB, Von Haven R, Mitchell DL (1996) Diel and depth profiles of DNA photodamage in bacterioplankton exposed to ambient solar ultraviolet radiation. Mar Ecol Prog Ser 137:283-291

Kaiser E, Herndl GJ (1997) Rapid recovery of marine bacterioplankton activity after inhibition by UV radiation in coastal waters. Appl Environ Microbiol 63:4026-4031

Karentz D, Cleaver JE, Mitchell DL (1991a) Cell survival characteristics and molecular responses of Antarctic phytoplankton to ultraviolet-B radiation. J Phycol 27: 326-341

Karentz D, McEuen FS, Land MC, Dunlap WC (1991b) Survey of mycosporine-like amino acid compounds in Antarctic marine organisms: potential protection from UV exposure. Mar Biol 108:157-166

Kraay GW, Zapata M, Veldhuis MJW (1992) Separation of chlorophylls $\mathrm{C}_{1}, \mathrm{C}_{2}$ and $\mathrm{C}_{3}$ of marine phytoplankton by reversed-phase-c18-high-performance liquid chromatography. J Phycol 28:708-712

Laurion I, Vincent WF (1998) Cell size versus taxonomic composition as determinants of UV-sensitivity in natural phytoplankton communities. Limnol Oceanogr 43:1774-1779

Lyons MM, Aas P, Pakulski JD, Van Waasbergen L, Miller RV, Mitchell DL, Jeffrey WH (1998) DNA damage induced by ultraviolet radiation in coral-reef microbial communities. Mar Biol 130:537-543

Mackey MD, Mackey DJ, Higgins HW, Wright SW (1996) CHEMTAX - a program for estimating class abundances from chemical markers: application to HPLC measurements of phytoplankton. Mar Ecol Prog Ser 144:265-283

Madronich S, McKenzie RL, Caldwell MM, Bjorn LO (1995) Changes in ultraviolet radiation reaching the Earth's surface. AMBIO 24:143-152

Mitani H, Uchida N, Shima A (1996) Induction of cyclobutane pyrimidine dimer photolyase in cultured fish cells by UVA and blue light. Photochem Photobiol 64:943-948

Neale PJ, Cullen JJ, Davis RF (1998a) Inhibition of marine photosynthesis by ultraviolet radiation: variable sensitivity of phytoplankton in the Weddell-Scotia Confluence during the austral spring. Limnol Oceanogr 43:433-448

Neale PJ, Davis RF, Cullen JJ (1998b) Interactive effects of ozone depletion and vertical mixing on photosynthesis of Antarctic phyoplankton. Nature 392:585-589

Paul JH, Jeffrey WH, DeFlaun M (1985) Particulate DNA in subtropical oceanic and estuarine planktonic environments. Mar Biol 90:95-101

Roza L, van der Wulp KJM, McFarlane SJ, Lohman PHM, Baan RA (1988) Detection of cyclobutane thymine dimers in DNA of human cells with monoclonal antibodies raised against a thymine dimer-containing tetranucleotide. Photochem Photobiol 48:627-633

Sancar A, Sancar GB (1988) DNA repair enzymes. Annu Rev Microbiol 57:29-67

Setlow RB, Swenson PA, Carrier WL (1963) Thymine dimers and inhibition of DNA synthesis by ultraviolet radiation of cells. Science 142:1464-1465

Smith RC, Baker KS (1979) Penetration of UV-B and biologically effective dose-rates in natural waters. Photochem Photobiol 29:311-323

Stockner JG (1988) Phototrophic picoplankton: an overview 
from marine and freshwater ecosystems. Limnol Oceanogr 33:765-775

Swenson PA, Setlow RB (1966) Effects of ultraviolet radiation on macromolecular synthesis in Escherichia coli. J Mol Biol 15:201-219

Tyrrell RM (1986) Repair of genetic damage induced by UV-B (290-320 nm) radiation. In: Worrest RC, Caldwell MM (eds) Stratospheric ozone reduction, solar ultraviolet radiation and plant life. Springer-Verlag, Berlin, p 139-149

Veldhuis MJW, Kraay GW (1990) Vertical distribution and pigment composition of a picoplanktonic prochlorophyte in the subtropical North Atlantic: a combined study of HPLC-analysis of pigments and flow cytometry. Mar Ecol Prog Ser 68:121-127

Veldhuis MJW, Cucci TL, Sieracki ME (1997) Cellular DNA content of marine phytoplankton using two new fluorochromes: taxonomic and ecological implications. J Phycol 33:527-541

Vink AA, Bergen HJBA, Nikaido O, Baan RA, Roza L (1994) Removal of UV-induced DNA lesions in mouse epidermis soon

Editorial responsibility: William Li,

Dartmouth, Nova Scotia, Canada after irradiation. J Photochem Photobiol B Biol 24:25-31

Visser PM, Snelder E, Kop AJ, Boelen P, Buma AGJ, van Duyl FC (1999) Effects of UV radiation on DNA photodamage and production in bacterioplankton in the coastal Caribbean Sea. Aquat Microb Ecol 20:49-58

Weinbauer MG, Wilhelm SW, Suttle CA, Garza DR (1997) Photoreactivation compensates for UV damage and restores infectivity to natural marine virus communities. Appl Environ Microbiol 63:2200-2205

Weinbauer MG, Wilhelm SW, Suttle CA, Pledger RJ, Mitchell DL (1999) Sunlight-induced DNA damage and resistance in natural viral communities. Aquat Microb Ecol 17: 111-120

Wilhelm SW, Weinbauer MG, Suttle CA, Pledger RJ, Mitchell DL (1998) Measurements of DNA damage and photoreactivation imply that most viruses in marine surface waters are infective. Aquat Microb Ecol 14:215-222

Zagarese HE, Tartarotti B, Cravero W, Gonzalez P (1998) UV damage in shallow lakes: the implications of water mixing. J Plankton Res 20:1423-1433

Submitted: November 23, 2000; Accepted: March 28, 2001 Proofs received from author(s): June 21, 2001 